\title{
Production and characterization of a monoclonal islet cell surface autoantibody from the BB rat
}

\author{
C.-H. Brogren ${ }^{2 *}$, F. Hirsch ${ }^{2}$, P. Wood ${ }^{1}$, P. Druet $^{2}$ and P.Poussier ${ }^{1}$ \\ ${ }^{1}$ McGill Nutrition and Food Science Centre, Montreal, Canada, and ${ }^{2}$ INSERM Unit U. 28, Hôpital Broussais, Paris, France
}

\begin{abstract}
Summary. Islet cell surface autoantibodies are present in the serum of the spontaneously diabetic BB rat. The availability in large quantities of such autoantibodies should help us understand their significance in vivo. Fusions between BB rat lymphocytes and rat myeloma cells were screened by cellular enzyme linked immunosorbent assay and indirect immunofluorescence on rat living cells. They resulted in a stable hybridoma, called $\mathrm{IC}_{2}$, secreting a monoclonal immunoglobulin $\mathrm{M}$ specific for the surface of rat islet cells. This monoclonal
\end{abstract}

antibody was found to bind to the surface of $56 \%$ normal rat islet cells and $72 \%$ rat insulinoma cells. Protease treatment of rat islet cells resulted in a subsequent $72-100 \%$ binding inhibition of $\mathrm{IC}_{2}$ to the surface of these cells, suggesting that $\mathrm{IC}_{2}$ specific antigen is a protein.

Key words: BB rat, rat monoclonal islet cell surface autoantibody.
The spontaneously diabetic BB rat currently represents, along with the NOD mouse, the best available animal model for Type 1 (insulin-dependent) diabetes $(1,2)$. Though the immune system appears more impaired in the $\mathrm{BB}$ rat than in Type 1 diabetic man, its involvement in the pathogenesis of B cell destruction is well established in both cases [3-5]. One of the main arguments in favor of such a role is the presence of circulating antipancreatic autoantibodies.

Such autoantibodies have been found in most Type 1 diabetic syndromes, whether spontaneous or virus-induced [6-8]. Islet cell surface antibodies (ICSA) have been shown to precede the onset of diabetes in the $\mathrm{BB}$ rat [9]. The presence of ICSA has been correlated with cytotoxicity for B cells in vitro in man and the BB rat $[10,11]$. Therefore, if antipancreatic autoantibodies are involved in the pathogenesis of B cell destruction, ICSA must be considered as the best candidates.

To obtain monoclonal autoantibodies specific for the surface of islet cells, we have hybridized lymphocytes from diabetic BB rats with rat myeloma cells. This report describes the generation and preliminary characterization of one stable rat hybridoma which produces a monoclonal immunoglobulin $\mathbf{M}$ specific for the surface of rat islet cells.

\footnotetext{
* Present address: Institute of Animal Physiology, The Royal Veterinary and Agricultural University, Copenhagen V, Denmark
}

\section{Materials and methods}

Inbred LOU rats were obtained from the National Institutes of Health (Dr. C. Hansen, Bethesda, MD, USA) and diabetes-prone BB rats were kindly provided by Dr. Pierre Thibert (Ottawa, ON, Canada). Outbred Wistar rats were purchased from Charles River Laboratories, (St.Constant, QC, Canada). Diabetic BB rats were used for fusions within $48 \mathrm{~h}$ after the onset of overt diabetes [1].

Two different rat myeloma cell lines were used; both originated from the LOU/C rat strain. The Y. $3 \mathrm{Ag} 1.2 .3$ (provided by Dr. C. Milstein, Cambridge, UK) spontaneously secretes a kappa chain [12], whereas the IR $983 \mathrm{~F}$ is a non-secreting cell line (provided by Dr. H. Bazin, Louvain, Belgium) [13]. Four lines of other cells and several types of primary cultures were used to test for specificity of antibodies produced. RIN5F cells (NEDH rat insulinoma cell line) were supplied by Dr. A. Lernmark (Gentofte, Denmark). C58 (NT)D-I-G is a Wistar Furth rat T lymphoma cell line (provided by Dr. R. Hyman, Salk Institute, La Jolla, CA, USA). BRL is a Buffalo rat liver cell line (obtained by Dr. A. Bertolotti, CNRS, France). HIT-TI5 is a hamster insulinoma cell line (kindly provided by Dr. R. Santerre, Eli Lilly, Indianapolis, INd, USA). A primary culture of Wistar rat fibroblasts was initiated from a preparation of newborn Wistar rat pancreatic islets as described by Brundstedt [14]. Normal Wistar rat hepatocytes were isolated by collagenase digestion [15]. Wistar rat peritoneal macrophages were obtained by a standard method [13]. Normal rat islet cells were prepared as described previously [9].

Y.3 Ag 1.2.3, IR 983 F and C58 cells were cultured in DMEM medium containing $10 \%$ foetal calf serum (FCS) and $60 \mathrm{mg} / 1$ gentamycin. RIN5F cells, BRL cells and fibroblasts were grown in RPMI 1640 with $10 \%$ FCS and $60 \mathrm{mg} / 1$ gentamycin, while HIT-TI5 cells were grown in Ham's-F12 medium supplemented with $15 \%$ horse serum and $2.5 \%$ foetal calf serum. Culture media, foetal calf serum, horse serum and other supplements were purchased from Gibco Laboratories (Burlington, ON, Canada). 
Table 1. Results of the cellular enzyme linked immunosorbent assay

\begin{tabular}{lllllll}
\hline & $\begin{array}{l}\text { RIN5F } \\
\text { cells }\end{array}$ & $\begin{array}{l}\text { Nor- } \\
\text { mal } \\
\text { islet } \\
\text { cells }\end{array}$ & & $\begin{array}{l}\text { BRL } \\
\text { Cells }\end{array}$ & $\begin{array}{l}\text { C58 } \\
\text { (NT) } \\
\text { D-1-G } \\
\text { Cells }\end{array}$ & $\begin{array}{l}\text { Fibro- } \\
\text { blasts }\end{array}$ \\
\hline $\begin{array}{l}\text { Monoclonal } \\
\text { antibody } \\
\text { IC } 2\end{array}$ & 0.278 & 0.241 & 0.035 & 0.003 & 0.027 & 0.034 \\
$\begin{array}{l}\text { Control } \\
\begin{array}{l}\text { Monoclonal } \\
\text { Antibody }\end{array}\end{array}$ & 0.021 & 0.011 & 0.044 & 0.000 & 0.004 & 0.000 \\
\hline
\end{tabular}

Supernatants of $\mathrm{IC}_{2}$ and control monoclonal immunoglobulin $\mathrm{M}$ were tested on the same number of six types of live rat cells. The values represent the mean optical density of duplicate evaluations. Blanking was obtained by replacing the primary antibody with buffer alone

Rat myeloma cells were used for fusion after a week of exponential growth. They were mixed with the BB rat lymphocytes (isolated by teasing of spleen and lymph nodes) in a 1:5 ratio and fused in the presence of polyethylene glycol as previously described [12,13]. Cells were then plated in 24 and 96 well plates at a concentration of $10^{6}$ cells $/ \mathrm{ml}$ in DMEM, 20\% FCS, $2 \%$ HAT on a feeder layer of Wistar rat peritoneal cells or erythrocytes. Screening of the supernatants was performed 15 to 25 days after the fusion. Cloning of hybridomas was performed by two successive limiting dilutions. Several fusions involved $\mathrm{BB}$ rat lymphocytes which had been prestimulated in vitro for $24 \mathrm{~h}$ with lipopolysaccharide (LPS, $5 \mu \mathrm{g} / \mathrm{ml}$ ) (Difco Laboratories, St. Laurent, QC, Canada). After cloning, hybridomas were grafted first subcutaneously and then intraperitoneally (for ascites production) into histocompatible (LOU/M $\times$ BB) $\mathrm{F}_{1}$ animals.

The heavy and light chain isotype of the monoclonal antibodies (MAB) was determined by Ouchterlony's technique using specific antisera kindly provided by Dr. H. Bazin as previously described [13]. The mouse monoclonal antibody MARK-1, specific for rat kappa chain, was used to purify monoclonal antibodies with kappa light chain (more than $95 \%$ of rat Ig have kappa chains) by affinity chromatography as previously described [16].

\section{Screening of hybridoma supernatants}

Culture supernatants were screened by an indirect immunofluorescence (IF) and a cellular enzyme linked immunosorbent assay (CELISA) for antibodies reactive with the surface of living RIN5F cells. For IF, RIN5F cells grown as monolayers were detached with Dulbecco phosphate buffered saline without calcium and magnesium (D-PBS, CMF). After two washes in RPMI 1640, 5\% FCS $10^{6}$ cells were incubated for $30 \mathrm{~min}$ at $4^{\circ} \mathrm{C}$ in $100 \mu$ of supernatant. After two rinses, the cells were incubated for $30 \mathrm{~min}$ at $4^{\circ} \mathrm{C}$ with $100 \mu$ l of affinity purified goat antibody to rat $\operatorname{IgM}$ and $\operatorname{IgG}$ conjugated with fluorescein (Cappel Laboratories, Malveen, PA, USA). After washing, the cells were resuspended in medium with $0.1 \% \mathrm{NaN}_{3}$ and examined for surface fluorescence with a Leitz microscope.

For the CELISA, RIN5F cells were detached with D-PBS, CMF and distributed into a flexible, V-shaped, polyvinyl-chloride, 96-well microtitration plate (Dynatech Laboratories Inc., Alexandria, VA, USA) at a concentration of $2.5 \times 10^{5}$ cells per well. The plate was centrifuged for $5 \min \left(2000 \mathrm{rpm}, 4^{\circ} \mathrm{C}\right)$ and the supernatant discarded. The plate was then vortexed to resuspend the cell pellet and $100 \mu \mathrm{l}$ of supernatant was added to each well (each supernatant was tested in duplicate). After a 90 -min incubation at $4{ }^{\circ} \mathrm{C}$, the cells were washed three times and resuspended in $100 \mu \mathrm{l}$ of affinity purified sheep antibody to rat IgM and IgG conjugated with peroxidase (Cappel Laboratories, Malvern, PA, USA). After another $90 \mathrm{~min}$ incubation, the cells were washed five times and then transferred to another microtitration plate to avoid any non-specific binding of the different reagents to the plas- tic. After the fifth wash, cells were resuspended in $200 \mu \mathrm{l}$ of D-PBS, CMF. The PVC plate was put on top of a rigid, flat bottomed 96-well microtitration plate (Nunc Laboratories, Kamstrup, Denmark). The bottom of each upper well was then punched with an 18-gauge needle with trocar in place (Becton Dickinson \& Co., Rutherford, NJ, USA) and the plates were centrifuged on top of each other for five min $\left(2000 \mathrm{rpm}, 4^{\circ} \mathrm{C}\right)$. The supernatant was flicked out of the rigid plate. The cells then were resuspended in $100 \mu$ l of a o-phenylenediamine (Sigma Laboratories, St. Louis, MO, USA) solution $(2 \mathrm{mg} / \mathrm{ml}$ in phosphate-citrate buffer, pH5 with $0.1 \% \mathrm{H}_{2} \mathrm{O}_{2}$ ). The enzymatic reaction was allowed to proceed for $15 \mathrm{~min}$ at room temperature and then was stopped by the addition of $\mathrm{HCl}, 4 \mathrm{~N}$. The absorbance was read at $492 \mathrm{~nm}$ in an automatic ELISA reader (Flow Laboratories, Mississauga, ON, Canada). The intraassay and interassay variabilities were found to be $12 \%$ and $17 \%$ respectively.

\section{Assessment of islet cell surface specificity}

When monoclonal antibodies were found to react with the surface of RIN5F cells in both IF and CELISA assays, their specificity for rat islet cell surface determinants was assessed using the same tests on different types of rat living cell suspensions. Controls were normal rat affinity-purified immunoglobulins (Calbiochem-Behring, La Jolla, CA, USA) or other rat MABs of the same isotype, but different specificities and used at the same concentration. The monoclonal antibodies were also tested by IF on $4 \mathrm{um}$ unfixed cryostat sections of rat pancreas, thyroid, brain, stomach, kidney, thymus, adrenal gland and liver using the same reagents and incubation times as for cell suspensions. In addition, adsorption tests on different types of cells were carried out: equivalent volumes of supernatant and cells were mixed for $60 \mathrm{~min}$ at $37^{\circ} \mathrm{C}$ and subsequently for $30 \mathrm{~min}$ at $4{ }^{\circ} \mathrm{C}$, then separated and tested against RIN5F cells as described.

To characterize the biochemical nature of the target antigen on the surface of islet cells, dispersed RIN5F cells $\left(10^{6}\right)$ were incubated at $37^{\circ} \mathrm{C}$ for $15 \mathrm{~min}$ with $500 \mu \mathrm{g}$ enzyme/ml D-PBS, CMF for pronase (pH 7.5), trypsin (pH 7.5), ficin ( $\mathrm{pH} 6.0$ ), chymotrypsin ( $\mathrm{pH} 7.5$ ) or for $60 \mathrm{~min}$ with protease-, aldolase-, and lecithinase-free neuraminidase $(1 \mathrm{U} / \mathrm{ml}, \mathrm{pH} 6.0)$ as described in [17]. Proteolytic enzymes were purchased from Boehringer Mannheim (Indianapolis, IN, USA), neuraminidase from Calbiochem-Behring Corp. (San Diego, CA, USA). Control incubations were carried out with buffer alone. After washing, monoclonal antibody binding to RIN5F cells was assessed by CELISA as described above.

\section{Statistical analysis}

Statistical analysis of the results (Wilcoxon's test) was performed with a statistical analysis package (Statpac, Walonick Associates, Minneapolis, Minn, USA) on an IBM personal computer.

\section{Results}

Twenty-four fusions have been made with either IR 983 F or Y.3 Ag 1.2.3 rat myeloma cells. The percentage of wells with growing hybridomas was high $(>80 \%)$. However, most of the secreted antibodies which gave a positive reaction during the screening on RIN5F cells were found to be nonspecific for a particular cell type. Some of them were shown to react with cytoskeletal antigens as assessed by specific ELISA (P. Poussier, unpublished data). One fusion resulted in a stable hybridoma producing a monoclonal antibody specific for the surface of rat islet cells. The fusion involved Y.3 Ag 1.2.3 cells and LPS-prestimulated BB lymphocytes. This 

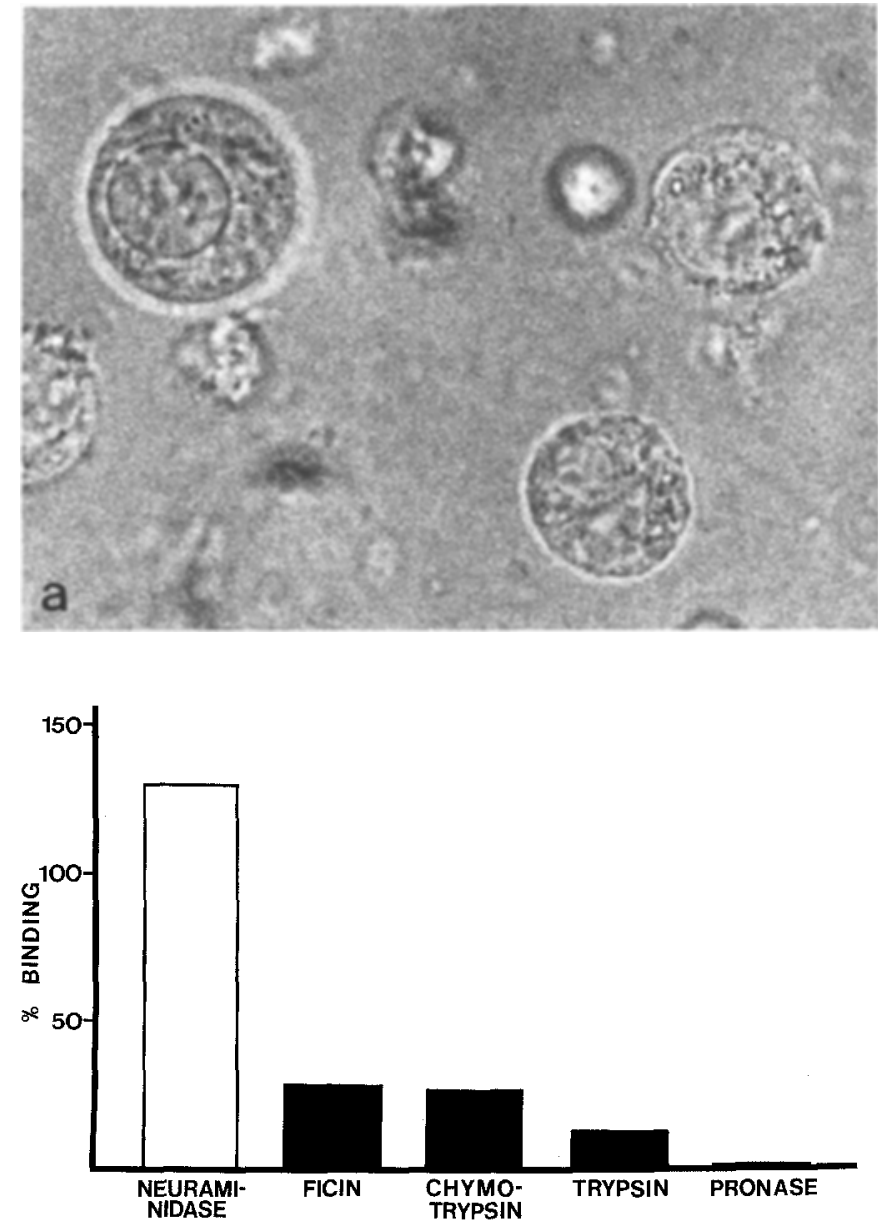

Fig. 2. Binding of $\mathrm{IC}_{2}$ to the surface of RIN5F cells after exposure of these cells to different enzymes. Results are expressed on the Y-axis as the percentage of control absorbance values (assessed in cellular enzyme linked immunosorbent assay) observed after binding of $\mathrm{IC}_{2}$ to enzyme exposed cells

monoclonal antibody, called $\mathrm{IC}_{2}$, was shown to be an IgM with kappa light chains. Table 1 illustrates the results obtained in the CELISA with $\mathrm{IC}_{2}$ and a control monoclonal antibody on different types of rat living cells. A positive response was observed only when $\mathrm{IC}_{2}$ was tested on RIN5F or normal rat islet cells. In contrast, there was no difference between $\mathrm{IC}_{2}$ and negative control when C58, BRL, fibroblasts or hepatocytes were used as target cells. When tested by CELISA on RIN5F cells, the optical density obtained after adsorption of $\mathrm{IC}_{2}$ on RIN5F cells was 0.015 vs 0.315 without prior adsorption. This response was not significantly different from that of the control monoclonal antibody. In contrast, prior adsorption of $\mathrm{IC}_{2}$ on $\mathrm{BRL}$ cells decreased minimally the OD $(0.244$ vs 0.298$)$, which is not significantly different from unadsorbed $\mathrm{IC}_{2}$. Thus $\mathrm{IC}_{2}$ reacted only with RIN5F and normal rat islet cells in the CELISA. The results were confirmed by indirect immunofluorescence on rat living cell suspensions (Fig. 1): it bound to the surface of $72 \pm 27 \%$ of RIN5F and $56 \pm$ $5 \%$ of normal rat islet cells (mean $\pm \mathrm{SD}, n=6$ ). In contrast, it did not react with the surface of the other rat cells (i. e. erythrocytes, fibroblasts, hepatocytes, macro-

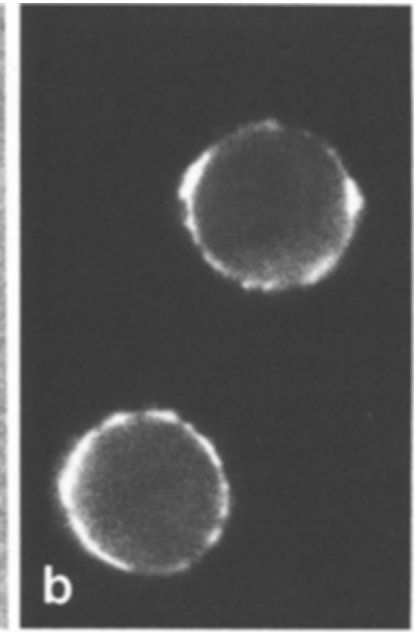

Fig. 1A and B. Indirect immunofluorescence staining of normal rat islet cells incubated with $\mathrm{IC}_{2}(1: 50$ dilution of ascites fluid) followed by staining with FITC conjugated goat antirat $\operatorname{IgM}$. A Phase contrast photomicrograph of three islet cells. B Fluorescence photomicrograph of the same field as in A showing the surface staining pattern on two of the islet cells $(\times 400)$

phages, C58 or BRL cells). However, when tested on HIT-TI5 cells (hamster insulinoma cells) IC $_{2}$ was found to label the surface of $95 \pm 3 \%$ of the cells.

Neuraminidase treatment of RIN5F cells failed to affect binding of IC2 to the surface of these cells (Fig. 2). In contrast, treatment of RIN5F cells by proteolytic enzymes reduced subsequent $\mathrm{IC}_{2}$ binding by $72-100 \%$. These results suggest that $\mathrm{IC}_{2}$ specific islet cell surface antigen is a protein.

\section{Discussion}

The spontaneously diabetic BB rat shows circulating ICSA as well as autoantibodies specific for multiple organs $[1,9]$. This study illustrates that hybridization of diabetic BB rat lymphocytes with rat myeloma cells can result in a stable hybridoma secreting a monoclonal autoantibody binding to the surface of rat islet cells. Indeed, among the different rat cells which were used in IF and CELISA to assess the specificity of $\mathrm{IC}_{2}$, only rat islet cells (either normal or tumoural) were found to carry on their surface an epitope bound by $\mathrm{IC}_{2}$. Furthermore, binding of $\mathrm{IC}_{2}$ to the surface of rat islet cells was abrogated by its prior adsorption on RIN5F cells, but not on other cells. The cross reactivity of $\mathrm{IC}_{2}$ with the surface of normal rat islet cells and rat insulinoma cells confirms similar results observed with circulating antipancreatic autoantibodies in the BB rat [9]. Similarly, Yokono et al. [18] have produced a monoclonal islet cell surface autoantibody (3A4) in the NOD mouse which binds to the surface of normal mouse and rat islet cells, as well as hamster insulinoma cells. The lack of species specificity appears to be a common characteristic of $3 \mathrm{~A} 4$ and $\mathrm{IC}_{2}$ since both bind to the surface of hamster insulinoma cells.

Human and mouse monoclonal antibodies reacting with the cytoplasm of islet cells have been obtained [6, 19]. On the other hand, immunization of mice with rat islet cells or chicken embryo retina cells resulted in mouse monoclonal antibodies specific for ganglioside antigens present on the surface of islet cells [17, 20]. These mouse monoclonal antibodies gave an ICSA-like 
pattern when tested on cell suspensions, but an ICAlike pattern when tested on pancreatic sections. This observation has been extended to question the duality of ICA and ICSA which are found in Type 1 diabetic syndromes [21]. $\mathrm{IC}_{2}$ which binds to the surface of a relatively high percentage of normal rat islet cells, failed to label these cells when tested by indirect IF on cryostat sections of rat pancreas even at high concentrations (data not shown). It also failed to label cryostat sections of other rat organs. We do not have a satisfactory explanation for this observation, except that cell surface antigens are probably less numerous on cryostat sections than on cell suspensions. It might also suggest that $\mathrm{IC}_{2}$ is specific for an islet cell surface antigen different from those bound by the ganglioside specific mouse monoclonal antibodies. One of these mouse monoclonal antibodies, R2D6, binds to the surface of normal, but not tumoural rat islet cells. R2D6 binding is inhibited by neuraminidase treatment of rat islet cells, but remains unaffected by protease treatment of these cells. In contrast, IC2 reacts with the surface of both normal and tumoural rat islet cells, and its binding is almost completely abrogated by protease treatment of these cells. In contrast to ICSA, ICA have not been reported in the serum of the $\mathrm{BB}$ rat. Their apparent absence, as well as the failure of $\mathrm{IC}_{2}$ to react with islet cells on cryostat sections, seems unlikely to be related to a technical difficulty since many laboratories have tried to find them. On the other hand, the NOD mouse monoclonal antibody $3 \mathrm{~A} 4$ has not been reported to bind to pancreatic sections either, suggesting that its specificity could be similar to that of $\mathrm{IC}_{2}$ especially when one considers that both react with the surface of normal rat islet cells and hamster insulinoma cells.

The availability of monoclonal islet cell surface autoantibodies such as $\mathrm{IC}_{2}$ or $3 \mathrm{~A} 4$ in animal models of Type 1 diabetes should be helpful in the understanding of antipancreatic autoimmunity particularly when they, as in the case of $\mathrm{IC}_{2}$, have isotypes expected to react with the complement system [22].

Acknowledgments. The secretarial help of J. Blais is gratefully acknowledged. This work was supported by a grant from the Medical Research Council of Canada (MA-8569). Dr. Brogren was the recipient of a fellowship award from INSERM, France. Dr. Poussier is the recipient of an MRC scholarship (no.1520). The cell fusion resulting in $\mathrm{IC}_{2}$ was made in Hagedorn Research Laboratories, Copenhagen, Denmark, screened in Paris, France and further characterized in Montreal, Canada.

\section{References}

1. Marliss EB, Nakhooda AF, Poussier P, Sima AAF (1982) The diabetic syndrome of the "BB" Wistar rat: possible relevance to Type 1 (insulin-dependent) diabetes in man. Diabetologia 22: 225-232

2. Makino S, Kunimoto K, Muraoka Y, Mizushima Y, Katagiri K, Tochino $Y(1980)$ Breeding of a non-obese diabetic strain of mice. Exp Anim 29: 1-13

3. Naji A, Silvers WK, Barker CF (1983) Autoimmunity and type I (insulin-dependent) diabetes mellitus. Transplantation 36: $355-360$
4. Yale JF, Marliss EB (1984) Altered immunity and diabetes in the BB rat. Clin Exp Immunol 57:1-11

5. Brogren C-H, Baekkeskov S, Dyrberg T, Lernmark A, Marner B, Nerup J, Papadopoulos G (1984) Role of islet cell antibodies in the pathogenesis of type I diabetes. In: Diabetes and immunology. Pathogenesis and immunotherapy. Kolb $\mathrm{H}$, Schernthaner $\mathrm{G}$, Gries FA (eds) Hans Huber, Bern Stuttgart Vienna, pp 65-78

6. Haspel MV, Onodera T, Prabhakar BS, McClintock PR, Essami K, Ray UR, Yagihashi S, Notkins AL (1983) Multiple organ-reactive monoclonal autoantibodies. Nature 304: 73-76

7. Doniach D, Bottazzo GF (1977) Autoimmunity and the endocrine pancreas. In: Ioachim HL (ed) Pathology annual, Vol. 7. Appleton Century-Crofts. New York, pp 217-223

8. Lernmark A, Freedman Z, Hofmann C, Rubenstein AH, Steiner DF, Jackson RL, Winter RJ, Traisman HS (1978) Islet-cell surface antibodies in juvenile diabetes mellitus. N Engl J Med 229: $378-380$

9. Dyrberg T, Poussier P, Nakhooda AF, Marliss EB, Lernmark A (1984) Islet cell surface and lymphocyte antibodies often precede the spontaneous diabetes in the BB rat. Diabetologia 26: 159-165

10. Dobersen MJ, Scharff JE (1982) Preferential lysis of pancreatic B-cells by islet cell surface antibodies. Diabetes 31: 459-462

11. Laborie C, Sai P, Feutren G, Debray-Sachs M, Poussier P, Marliss EB, Grose M, Assan R (1985) Time course of cytotoxic islet cell antibodies in the BB rat. Diabetes 34: 904-910

12. Galfre G, Milstein C, Wright B (1979) Rat X rat hybrid myelomas and a monoclonal anti-Fd portion of mouse IgG. Nature 277: 131-133

13. Bazin H (1982) Production of rat monoclonal antibodies with the LOU rat non secreting IR983F myeloma cell line. In: Peeters H (ed) Protides of the biological fluids. 29th Colloquium 1981. Pergamon, Oxford New York, pp 615-618

14. Brundstedt $J$ (1980) Rapid isolation of functionally intact pancreatic islets from mice and rats by Percoll ${ }^{\mathrm{TM}}$ gradient centrifugation. Diabete Metab 6: 87-89

15. Seglen PO (1973) Preparation of rat liver cells. Exptl Cell Res 82: 391-398

16. Bazin H, Xhurdebise LM, Burtonboy G, Lebacq AM, DeClercq L, Cormont F (1984) Rat monoclonal antibodies. I. Rapid purification from in vitro culture supernatants. J Immunol Methods 66: 261-264

17. Alejandro L, Shienvold FL, Vasiewyck-Hajek SA, Pierce M, Paul $R$, Mintz D (1984) A ganglioside antigen on the rat pancreatic B cell surface identified by monoclonal antibody R2D6. J Clin Invest 74:25-38

18. Yokono K, Shii K, Hari J, Yaso S, Imamura Y, Ejuri K, Ishihara K, Fuju S, Karzumi T, Tamiguchi H, Baba S (1984) Production of monoclonal antibodies to islet cell surface antigens using hybridization of spleen lymphocytes from non-obese diabetic mice. Diabetologia 26: 379-385

19. Satoh J, Prabhakar BS, Haspel MV, Ginsberg-Felluer F, Notkins AL (1983) Human monoclonal autoantibodies that react with multiple endocrine organs. N Engl J Med 309: 217-220

20. Eisenbarth GS, Shimizu K, Bowring MA, Wells S (1982) Expression of receptors for tetanus toxin and monoclonal antibody A2B5 by pancreatic islet cells. Proc Natl Acad Sci USA 79: 5066-5070

21. Nayak RC, Omar MAK, Rabizade A, Srikanta SV, Eisenbarth GS (1985) "Cytoplasmic" islet cell antibodies: evidence that the target antigen is a sialoglycoconjugate. Diabetes $34: 617-619$

22. Medgyesi GA, Füst G, Gergely J, Bazin H (1978) Classes and subclasses of rat immunoglobulins: interaction with the complement system and with staphylococcal Protein A. Immunochemistry 15: $125-129$

Received: 10 December 1985

and in revised form: 20 March 1986

\section{Dr. P.Poussier}

McGill Nutrition and Food Science Centre

Royal Victoria Hospital

687 Pine Avenue, West

Canada H3A 1A1 